It'NDF. NFME II is a graduate student at the Institute of Canadian Studies. Carleton I'niversity, and has previously worked as an editor and writer. Her Master's thesis will compare Canadian feminist writing in French and English. She is also involved in Breaking the Silence, a feminist quarterly journal, and in Ottawa Women and Words.

\title{
Present? or Re-Present?
}

TÜNDE NEMETH

IMAGINE a woman.

Better yet, I'll help you imagine a woman. A woman is "belle, grosse, féminine, effrontée, charmante, maigrichonne. Pas pire, brillante la petite." A woman is a blank page upon which these adjectives can be inscribed. Adjective, never noun. Nommée, jamais nom. Object, never subject. "Other", or "they", never "I" or "we". Silent, voiceless, a mute muse. A blank space waiting to be filled by my words. Woman is absence. Woman does not exist.

When I tell you about woman, when I write about her, I fill that blank page. I assume her absence. Then I create her in whatever image I, author, choose. I take control of her. Secure in the knowledge that she is still absent, even though I describe her, I can re-present her to you with authority. I want you to accept my version of her, not to question my author-ity. I therefore define myself as omniscient author, as "a subject who is supposed to know," and who attempts "to find an invariant meaning" 2 that you, the reader, either accept or reject.

1. "L'écrivain," in La nef des sorcières (Ottawa: Quinze, 1976), p. 74. All subsequent references will be given in the text, with the abbreviation NS and a page number. My thanks to Patricia Smart for all her encouragement and editorial comments.

2. Alice A. Jardine, Gynesis: Configurations of Woman and Modernity (Ithaca: Cornell University Press, 1985), p. 118. 
Without "representation", scholarly, technical and other "objective" writing would not be possible. This process of representation "is the process of analysis: naming, controlling, remembering, understanding. ... [it] confirms the possibility of an imitation (mimesis) based on the dichotomy of presence and absence." 3

It is this dichotomy of presence and absence that is so problematic for women. If we have always been the blank space between the lines, if we have always lived in the margins, we have been absent from text. Our absence as subjects - even in our own writing, as, for example, in the Vi torian novel - has made it possible for others to re-present us as object and as adjective, has made it impossible for us to speak for ourselves, to discover our own voices. Representation itself is thus problematic, particularly for women who write and who want to inscribe themselves as subjects "sans tuer autour", (France Théoret) or without killing everything around them in order to better offer it up, describe it, to their readers.

If the idea of representation is thrown into question, so too are all forms of writing and art that make use of it: hence writing a critical article that uses representation to discuss representation itself is fraught with irony. By using representation, defining it, making it conscious, I create a contradiction: I am making it both absent and present. For the purpose of this article, I assume you know nothing about it, therefore I make it absent, then proceed to tell you all about it. But by telling you about it, I also show you how it works, therefore I also make it present.

I balk at trying to re-present the work of two authors - France Théoret and Nicole Brossard - who write not with object-ivity but with subjectivity, and in whose work women are present, not absent. I balk partly because of the irony, and partly because of the difficulty in representing work that is itself largely non-representational. Yet if I chose not to represent the work, I would resort to telling you, to paraphrase Alice Jardine, please just read the originals for yourselves, ${ }^{4}$ and participate in the text yourselves. I therefore proffer this re-presentation, aware however of the distortions it may engender.

3. Ibid., pp. 118-19.

4. Ibid., pp. 118. 
Both Théoret and Brossard concern themselves consciously with representation and women's relationship to it. The concept underlies and informs both Une voix pour Odile and "L'écrivain," while it is the central concern of "Cet angle qui nous échappe cruelle ambivalence." subverts representation by concentrating solely on the emergence of voice, not on image. Brossard, by contrast, focuses primarily on the problem of image for women - in particular for women writers.

In Une voix pour Odile, Théoret consciously writes from the margins "la marge me sert de cadre" (VO 11); she addresses the question of herself as Other, as blank space:

Je suis autre, éclatement, morceaux de journées, images du corps ou représentation toujours gardée présente. Je suis le manque, me vois et me vis ainsi travaillée par des voix qui m'assaillent, polluée par toutes les idées, images, mythes que la société se fait de toutes les femmes, et par conséquent, de moi. (VO 59)

Brossard talks about growing up an adjective, defined by others (as quoted above, from NS 74); her text itself (L'écrivain") acknowledges her absence as subject, as writer, in the use of the masculine form of "écrivain" (NS 76) when she refers to herself. This masculine-as-neuter gender emphasizes the contradiction in being a woman and a writer, by the juxtaposition of the two in "je sors de ma cachette de femme et d'écrivain" (NS 76).

Both Brossard and Théoret pick up the image or representation of women as "femme fatale". Théoret questions and dismisses it - "Pourquoi dit-on femme fatale? Ce n'est pas qu'une question d'imagination" (VO 11) - while Brossard engages it, embraces it, then appropriates it as positive:

Femmes fatales. Nous sommes sûrement fatales à quelqu'un, à quelque chose pour subir le mauvais sort. Oui, je veux être fatale à l'amour emmuré. Fatale à la famille, fatale aux polices d'assurances, fatale à nos gardes du corps. (NS 78)

5. France Théoret. Une voix pour Odile (Montreal: Les Herbes Rouges, 1978). Nicole Brossard, "Je vais tourner mon corps et faire semblant de la comparer," La nouvelle barre du jour 136-137 (mars 1984, numéro spécial sur femmes et photos): 149-60. All subsequent references to both will appear in parentheses in text, with the abbreviations VO and NBJ, respectively, followed by a page number. 
"Cet angle qui nous échappe cruelle am bivalence" struggles more fully with the idea of representation through the extended metaphor of a photo session in which the photographer is continually frustrated in her attempts to get the precise angle or image that she seeks. Through this frustration, she learns that she cannot present her model in the image she wants. This series of short pieces itself shows how even a photographic image, perhaps the quintessential representation, can be subverted by a woman who refuses to allow herself to be used, no matter how much the photographer may insist. In the series, Brossard directly confronts the problem of image, concluding that women need not allow themselves to be represented, and that texts written by women need not be representational. She shows, through the model's actions, how women can take control of how they are seen; through the text itself, how women can write "sans tuer autour."

What, specifically, makes "Cet angle" a model of a text that subverts representation? First and foremost, there is no "omniscient author" directing events and characters. In "La femme rapprochée," Brossard establishes that the roles of model and photographer are interchangeable by shifting from first person to second to third and back again in rapid succession. Eventually this is resolved, not by better differentiating the two, but by fusing them in "La femme dos à dos."

The lack of omniscient author establishes the presence of the characters in the text and invites the reader's active participation. The very first line draws the reader in by directing her attention to an action, to someone approaching who will change the idea of distance. With no omniscient description and no overt authorial control, ${ }^{6}$ the characters must speak for themselves, the reader must listen without authorial mediation. This presence is symbolized by the relationship between the photographer image-maker, analogous to "author" -and the model character. The latter takes responsibility for her own representation - for how she will allow herself to be photographed - away from the photographer. In "La femme retouchée" the model rips up the retouched image of herself that the photographer has carefully constructed out of fragments "pour bien [lui] montrer qu'elle savait faire les choses quand il s'agissait de son image" (NBJ 152). In "La femme approchée" the model walks out on the photographer, having taken off her blouse ("... for the sake of art"), having

6. Although, of course, this is a very tricky area, since there is an enormous amount of authorial control of language exhibited in the text. 
realized that it made her feel uncomfortable and embarassed. Again the model rejects the photographer's insistence on the kind of image the latter wants to produce, one of the fragmented portions of the body, of "le cou, les clavicules, les seins, bien sûr, les épaules de dos. ... Je désirais me concentrer sur le mamelon évidemment elle ne se décidait pas et me parlait d'étranges sensations et de "gêne" (NBJ 153). Instead the photographer must settle for whatever image she can get, whatever the model chooses to allow her. On her way out, the model pauses for long enough to make a cryptic comment - "La ville est construite sur un mamelon" (NBJ 153; does she mean "hill" or "nipple" or both?) - and for the photographer to snap a picture of her whole body, which now fills the lens, rather than just the fragments she originally wanted. With this metaphor, Brossard demonstrates how women can implicate themselves in their own texts, that is, how they can assert a presence rather than allowing themselves to be represented.

She picks up this thread again in "La femme parlante", where she admits that "elle ne voulait pas parler, elle voulait tout simplement que nous nous regardions. ...tout était question de méthode pour arriver à l'image de soi désirée dans le regard de l'autre" (NBJ 155). She achieves this "method" through "la femme dos à dos", where the photographer and model have stopped fighting one another, where an initial sense of panic becomes wonder at the sensation of being able to see "partout à la fois" (NBJ 155) by standing back-to-back. The woman is satisfied with the image of herself in profile, back-to-back with another woman, as if standing with her back to a mirror.

Having arrived at this image of herself as she wishes others to see her, she can give voice to her "douce vision" (NBJ 156-60). In this vision, the "somebody" heralded at the beginning has arrived, the one who will transform the idea of distance, coming closer and closer until she is too close. But what was too close to allow for a sharply-focused picture in "La femme rapprochée" is now simply close enough to "tout faire à ma place quelle question si je dois passer à l'action" (NBJ 156). That is, she is close enough to become the " $I$ "-speaker herself. Hence, by transforming the idea of distance, shortening "la distance de soi à soi" (NBJ 156), Brossard transforms the idea of image, of representation: her vision is one of fusion of self and self ("soi [et] soi"), or self and image.

The implication for texts of having been successfully rid of the objective author-ity of traditional representation is a liberation of authentic voice. Applied to women, this means being able to break silences surrounding the realities of women's lives, especially those connected with the body, with creativity, and with women's oppression at all levels. One of these levels is that of language itself, of special concern to both 
Brossard and Théoret. Indeed, language and writing are absolutely central, and other concerns often revolve around the expression of that centrality. By avoiding the use of image almost entirely, Théoret in particular highlights the liberation and emergence of the authentic voice.

The freed voice can engage in wordplay, thereby also freeing language to express what it needs to say. This play occurs largely on the semantic level, although both Brossard and Théoret often confound otherwise "sound" syntax by using no punctuation. A dramatic example of this is "La femme retouchée", a headlong tumble of sentences piled on top of the other with not so much as a comma to guide the eye, except for one small white space (NBJ 151, 1. 11), the opening capital letter, and the closing period. By contrast, Brossard's earlier "L'écrivain" contains all the correct punctuation and, for the most part, grammar, even in the heat of writing about birthing.

Théoret often starts with something that looks like it will be a sentence, then turns into a list with no commas or other punctuation. She pushes at the borders of the language:

Qu'on s'le dise le j'me marie, j'me marie pas, j'fais une soeur Odile ses filles ses petites filles toutes vivantes dévorées par la grand machine de mort ont refait des noeuds tressés une vie à remettre aux autres. (VO 12)

...pourquoi cacher le chancre le hors-texte le sommeil la lassitude le quotidien de la femme dite sans profession. (VO 12-13)

Le sommeil la lassitude la paresse. ...Il ne reste rien sinon une voix un filet qui ne parvient pas à trouver son registre pas si fort c'est compris répète plus haut encore faudrait articuler marmonne pas soigne tes ti tes di roule pas tes $r$ un cri long aigu je déparle j'ai déparlé. (VO 15)

Théoret also engages in semantic play. In recounting her first, disastrous sale in the family restaurant when she sold a package of Lifesavers for five cents instead of six, she connects the homonyms "content" and "comptant" in a quick discussion of money, class and language: "L'appartenance de classe c'est tout ça, un langage aussi argent sonnant argent compté comptant content crédit chèque..." (VO 14). Similarly, she begins the last piece in Une voix pour Odile with a pun: "Piège le je, piège le jeu" (VO 76).

But by far the most exciting use of both semantic and syntactical play is Théoret's brilliant "Les ho! Les ha!" (VO 73). It begins with a tongue game. If you say the first sentence quickly enough - "les li les la les lo" - you produce vowel sounds which both have sense and 
are non-sense, and which are connected by "l" sounds (or the other way around!) that create delightful sensations on both tongue and palate. Although some of the words she explores evoke images from other parts of the book (goût, sang, passion, passivité, l'enfant, l'ennui), I find no hidden meanings, no pattern to this grouping of words. Apart from these observations, therefore, my re-presentation breaks down at this point; I can see only pure fun, hear only the joy of non-sense and a real love of the same language that traps and imprisons; I can only direct you back to the passage as an example of what I mean about the lengths to which the breakdown of language goes.

Brossard, on the other hand, also pushes at etymology in "Cet angle", with her play on the source meanings of "gêne" in "La femme approchée" (NBJ 153). Beginning with "gêne," a word that fits her narrative, she observes that its roots are "torture" and "avouer." From "aveu," she gets "hommage" (an old sense of the word) and "révélation," in the sense of "confession". There is more to this than immediately meets the eye, however; my quick perusal of Le Petit Robert yielded the information that "hommage" comes from "homme", while "révélation" has an additional meaning when used as a photographic term: "development" (of a photographic image). This last reflects back into the text, where another photographic term, "surexposer" (to overexpose) is hidden in a sentence concerning the model's embarassment: "Le malaise s'installait entre nous comme un trouble physique, une difficulté qu'il faudrait surmonter ou surexposer" (NBJ 153).

The voice, freed of the omniscient author and speaking its own language, can talk about itself: its silences, its self-reflection, its connection to the real woman behind the voice with the result that this real woman becomes firmly rooted, firmly present, in her own text, in the lines or in the spaces, exactly as she chooses.

Both Brossard and Théoret are deeply concerned with the ways in which women are silenced by language itself. In both "L'écrivain" and "Cet angle," Brossard refers to this silencing by simply mentioning the silent " $e$ " that marks the feminine gender in French: "tramer comme un ' $e$ ' muet mes phrases où le masculin l'emporte toujours sur le féminin" (NS 75). The silent " $e$ " on the second line of "Cet angle" is emphasized in italics to make the same point; further down the page when the model is asked, "tu l'épelles comment ton nom," she replies, "avec un e muet" (NBJ 151), as if this were the only important letter in her name. 
Théoret deals with a different aspect of women's silence: that of the difficulty of speaking and thinking, of saying what you mean, of putting your thoughts across in a hostile language. "Elle est muette," she says, "ou bégayante ou écrasée par le cri du dedans ou déparlante ou disant l'exact contraire de ce qu'elle veut dire" (VO 30). Elsewhere, she asks, "qui gauchit mes mots?" (VO 46), and later asserts: "Il n'y a pas de mots. Le verbe est mort. Une tâche urgente: circonscrire cet aveuglant mirage qui me coupe pendant de très longs moments du langage" (VO 60-61).

The paradox of being silenced by the very language in which you must express yourself produces sensations of detachment and disconnection, of surrealistic self-observation: "J'ai l'impression d'avoir flotté à côté de moi..." (NS 77); "Je me sens à côté de moi" (VO 60); "J'existe littéralement hors de moi" (VO 20). There is progress in Une voix pour Odile, however, as demonstrated by the re-connection and self-assertion in this passage:

Moi, France Théoret, je suis capable d'écrire depuis que mes mains m'apparaissent plissées, qu'on m'appelle souvent madame et que le matin, il me reste des yeux cernés ou enflés. Je ne me dédouble plus dans le miroir de ce que j'écris: je ne me vois pas écrivant. (VO 69)

The source of re-connection, the grounding or rooting that makes it possible, is to be found in the body. If language is central to the writing of France Théoret and Nicole Brossard, the body is central to language. The exhortations of Madeleine Gagnon, Luce Irigaray, Hélène Cixous and others to "write the body" are put into practice in these texts. The profound difference between writing the body and re-presenting the body is illustrated in Brossard s "Cet angle." The photographer, we recall, is only interesied in fragments of the model's body: the breast, the neck, the clavicle, the shoulders. In "La femme rapprochée," the entire sequence of producing the photographic image - to be ripped up, remember, in "La femme retouchée" - is shown to be patently false, through juxtaposition of contradictory statements: "ne souris pas c'est impossible fais la femme comme si tu étais une femme ne fais pas semblant de rien sois naturelle regarde devant toi comme si tu y trouvais une justification comme si je m'approchais pour t'embrasser ne bouge pas fais semblant de rien" (NBJ 151). The idea of the body in its wholeness surfaces in "La femme dos à dos", where Brossard refers to the other's back as "le mur de berlin pour appuyer mes reins..." (NBJ 154). This also introduces the importance of touching - here, touching provides each with support for her back. Later, Brossard gives touching precedence even over writing: "Je déposai le manuscrit et nous avons commencé ça au toucher. Nous y tenions absolument" (NBJ 158). 
Théoret set out to use the body to create a language: "Mon corps écrit d'un souffle chaud une langue" (VO 12). The voice and breath that come from the body itself give her a way of talking about writer's block and other difficulties centred in language and writing through the metaphor of premenstrual tension and waiting for the blood in "Le sang" (VO 48-50). From the beginning, and throughout, she links the two by using language of one, then the other, then language describing feelings that could apply to either:

... le sang qui ne veut pas venir.

Les bords, les marges, les étonnantes effusions, les rythmes étouffés. Je suis parcourue du ventre aux tempes de palpitations...

Je suis au sec. Ni larmes, ni sueur, ni sang.

Je veux voir mon sang. Connaitre l'obsession de la venue du sang... c'est en arriver à s'enfermer sur soi. Se refermer dans la prison. Mourir à l'infinitif d'une mort sans temps, ni lieu, ni foi, ni loi. Si, au contraire, certainement quelque part, l'intériorisation de la loi du père. (VO 48-49)

So skillfully is the tension maintained in this piece that the coming of the blood at last made me feel as relieved as if it were my own.

Brossard uses a more common image, even a cliché perhaps, to express the connection between her body and her creativity: that of childbirth (NS 78). Yet she too breaks the bond of representation and instead evokes the experience itself by describing in concrete detail what she feels during the experience. "Ceci est mon corps," she begins, then describes the contractions, the pushing, the dry mouth, sweat, heat and so on, through to the birth-orgasm and the announcement, "C'est une fille." Afterwards, she asks, "à qui appartient ce corps? Où fera-t-elle?" She then makes the connection between her writing and her body with "les pages se décollent. Les mots affluent autour du clitoris." This is followed immediately by another connection, this time between women's bodies and the patriarchy: "Toute jouissance du clitoris annonce un chavirement dans le corps historique de l'espèce"' (NS 78-79).

Speaking the body in this way articulates the connection between the real world and the textual world of writing. The body's presence in a text makes it impossible for that text to re-present the body. Through writing the body into the text, rather than describing it in the text, France Théoret and Nicole Brossard deliberately and subversively take charge of image and self, refusing the re-presentation imposed by others. The former refuses image altogether, concentrating instead on the emergence of voice; the latter confronts, controls, and subverts the very idea of image itself.

In our lives and in our writing, we must move beyond the alienating images that traditionally have been used to re-present our women's bod- 
ies. By writing the realities based in our own bodies, we can subvert those alienating images; we can change the very meanings of words, thereby taking control of ourselves. Our bodies can root us in our texts, if we listen to them and let them speak through our writing.

\section{Bibliography}

Burke, Carolyn Greenstein. "Report from Paris: Women's Writing and the Women's Movement." Signs: A Journal of Women in Culture and Society 3, no. 4 (1978): 843-55.

Eagleton, Terry. Literary Theory: An Introduction. Oxford: Basil Blackwell, 1983.

Gagnon, Madeleine, "My Body in Writing." In Feminism in Canada: From Pressure to Politics. Ed. Geraldine Finn and Angela Miles. Montreal: Black Rose Books, 1982.

Gallop, Jane. Feminism and Psychoanalysis: The Daughter's Seduction. London: The Macmillan Press Ltd., 1982.

Godard, Barbara. "Writing and Difference: Women Writers of Québec and English-Canada." In In the Feminine: Women and Words: Conference Proceedings 1983. Ed. Ann Dybikowski et al. Edmonton: Longspoon Press, 1985.

Irigaray, Luce. This Sex Which is Not One. Trans. Catherine Porter, with Carolyn Burke. Ithaca: Cornell University Press, 1985.

Showalter, Elaine. "Feminist Criticism in the Wilderness." In Writing and Sexual Difference. Ed. Elizabeth Abel. Chicagot University of Chicago Press, 1982.

Smart, Patricia. "Quand la fille du bar se met à parler: la poésie de France Théoret." Dalhousie French Studies, Special Issue (Summer 1985): $153-62$. 